\title{
GENDER SENSITIVITY TO PUBLIC SCHOOL ENROLMENT IN ONDO STATE, NIGERIA USING SYSTEMATIC SAMPLING
}

\section{ADEDAYO AMOS ADEWARA AND ADEBOLA ANTHONIA ADENIYI}

(Received 15 December 2015; Revision Accepted 3 March 2016)

\begin{abstract}
This study employed the total number of public schools in Ondo, Nigeria which gives information on the name of the school, males and females in each school from JSS1 to SS3 in the eighteen local government areas. Systematic sampling was used to select forty eight schools from the two hundred and eighty eight public schools in the state during the 2012/2013 and 2013/2014 academic sections. Applying the instrument of Pearson product moment correlation coefficient, the study revealed that (i).females are more sensitive to public school enrolment during 2012/2013 and 2013/2014 academic sessions than their males counterparts, (ii).there is significant difference between the female enrolments during the two academic sessions, (iii).there is significant difference between the male enrolments during the two academic sessions and (iv). the trend of male female enrolments in the selected public schools shows improvement during 2013/2014 over that of 2012/2013 academic session.
\end{abstract}

KEYWORD: Gender, Sensitivity, Systematic Sampling, School, Enrolment

\section{INTRODUCTION}

The foundation of any state is in the number of people who are literate in that particular state. This brings about the counting of young pupils who are enrolled in Ondo State public secondary schools from each local government areas and how the government has improved on the trainings being given to the teachers and infrastructure been given to schools in Ondo State so as to encourage the young pupils to attend public secondary schools than private secondary schools.

Ondo State is one of the six states that make up the South West geographical zone of Nigeria. It has interstate boundaries with Ekiti and Kogi States to the north, Edo State to the east, Delta State to the SouthEast, Osun State to the SouthWest and Ogun State to the SouthWest The Gulf of Guinea lies to its south and its capital is Akure. Dubbed as the Sunshine State, Ondo, which was created on February 3, 1976, it originally included what is now Ekiti State, which was split off in 1996. The State has a population of 3,441,024 persons (2006 census) distributed across eighteen local government areas which are Akoko North East, Akoko North West, Akoko South East, Akoko South West, Akure North, Akure South, Ese-Odo, Idanre, Ifedore, Ilaje, Ile-Oluji/Okeigbo, Irele, Odigbo, Okitipupa, Ondo East, Ondo West, Ose, Owo local government areas. The majority of the state's citizens live in urban centers. Within a land area of 15,195.2 square kilometers and lies at latitude $7^{0} 10^{1}$ north and longitude $5^{0} 05^{1}$ east and a population density of 218 people per square kilometer. It accounts for $2.5 \%$ of Nigeria's total population.

The State plays hosts to 880 public primary schools and 288 mixed public secondary schools and a number of tertiary institutions including the Federal
University of Technology, Akure, Adekunle Ajasin University, Akungba/Akoko, Ondo State polytechnic, Owo, Federal College of Agriculture, Akure and Adeyemi College of Education, Ondo.

There are 1,164 primary schools, 300 Junior Secondary Schools and 297 Senior Secondary Schools in the State. The total enrolment in primary school was 459,521 in 2008/2009 academic session; this gives an average of 395 Pupils per primary school. The total enrolment was 136,203 for Junior Secondary Schools and 117,201 Senior Secondary Schools which gives an average of 454 and 395 per school respectively (Ministry of Economic Budget and Planning, Ondo State, 2010) (Adeniyi, 2014) .

\subsection{METHODOLOGY}

Education is one of the most powerful instruments in shaping the human race. Education is the only answer to all our socio - economic problems (Tilak, 1987: Rena, 1995; 2007). Education is the basis of development. But unfortunately education in Nigeria is bisected with myriads of problems. These includes; poor funding and thus poor educational infrastructures, inadequate classrooms, teaching aids (projectors, Computers, Laboratories and libraries), paucity of quality teachers and poor/polluted learning environment. In addition to these inadequacies, our school system is plagued with numerous social vices such as examination malpractices, cultism, hooliganism and corruption.

Secondary education is divided into three years of junior secondary and three years of Senior Secondary School. The education that is offered at this level has two purposes. The one purpose is to prepare pupils to exit school with the necessary skills to find employment, and the other is to prepare them to continue with

Adedayo Amos Adewara, Department of Statistics, Federal University of Technology, Akure, Nigeria.

Adebola Anthonia Adeniyi, Department of Statistics, University of Ilorin, Ilorin, Nigeria. 
academic careers in higher education (Moja, 2000). Usman (2008), Taiwo (1983), Oni (1995) and Akpan (2007) all affirmed that secondary school education has been further fragmented - the junior level is now merged with the primary education and this is supported by the Federal Government. The three years of senior secondary school level is left untouched (Oruonye, 2014). The importance of secondary education in educational system cannot be overemphasized. Apart from serving as the link between primary and tertiary education. It provides opportunity for a child to acquire additional knowledge, skills, and traits beyond the primary level (Ige, 2013)

The influx of students to public secondary schools in Ondo State, Nigeria (Adeyemi, 2008) has been a matter of concern to stake holders in education (Ondo State Nigeria Ministry of Education, 2010). Common observation in the school system shows that input into the system were being provided by government at increasing numbers. Although, the output seems to be increasing, the quality of output however was perhaps at a fluctuating trend.

According to (Afolabi, 2008) who emphasized that the free secondary education in Ondo State has led to the rapid expansion of the Secondary School System. It is no gainsaying that such rapid expansion of the school system will bring about high demand for more school buildings, more qualified and competent teachers and clerical staff and instructional facilities for effective teaching and learning in the schools.

There is an imperative need to change the education pattern drastically and make it more purposeful. The purpose of education is to prepare the future citizens for carrying out their onerous tasks and responsibilities, to correlate scientific spirit and human aspirations and make the future citizens an essential instrument in ushering in happier and better times. The purpose of education should be to broaden the outlook and promote cultural levels of the students while enabling them to transgress the artificial barriers of ethnicity and religion.

The Nigerian educational system has witnessed a progressive change since independence in 1960. The Universal Basic Education (UBE) which was inaugurated in October, 1999 by the Federal Government of Nigeria has led to a considerable expansion of the school system. The free secondary education embarks upon by some states in the country including Ondo State has led to influx of students into secondary schools. Thus, the enrolment of students rose from 157,652 in 1999 to 210,520 in 2006 and to 244,712 in 2012 (Ondo State Nigeria Ministry of Education, 2013). Considering the explosion in students' enrolment in the schools, many variables tend to influence how a school system performs at a particular time. Some of these variables include school location, school size, class size, teacher student ratio, teachers' qualifications and teachers' teaching experience. School location in Ondo State, Nigeria could be seen in terms of urban and rural location of schools. Rural areas accounts for 170 secondary schools (57\%) in the State while urban schools accounts for the remaining 134 secondary schools (43\%) (Ondo State Government, 2010). The size of the school tends to vary from one place to another. In some places, there are schools with less than 1,000 students while in other places there are schools with more than 1,000 students. In Ondo State, Nigeria, schools having population of students of below 1,000 are regarded as small schools while schools having population of 1,000 and above are regarded as big schools (Ondo State Nigeria Ministry of Education, 2010). Class-size is an educational tool that can be used to describe the average number of students per class in a given institution. Much variation has been discovered in class-size in many countries of the world. This variation was identified by (Watson and Prieto, 2000) who compared the class-size in England and Spain and found out that "class-sizes in Spain are significantly higher than England especially in the 17-18 age range." According to them, the mean class-sizes in Spain for the age range 11-16 was about 34 while in England, it was about 26. They found that for the age 17-18 "the mean class-size in England reduced to 13 whereas in Spain, the mean class-size, remained almost the same as for earlier years."

\section{Research questions:}

(i). Are males more sensitive to public school enrolment during 2012/2013 academic session than females?.

(ii). Are males more sensitive to public school enrolment during 2013/2014 academic session than females?.

(iii). Is there any significant difference between the male enrolments during the two academic sessions?.

(iv). Is there any significant difference between the female enrolments during the two academic sessions?.

\section{Research design:}

The study was designed to study the gender sensitivity in the selected forty eight public schools from the two hundred and eighty eight schools in the state using systematic sampling with the following hypotheses with pearson product moment correlation coefficient as an instrument of comparison because of its known reliability.

\section{Hypotheses:}

(i). $\quad \mathrm{H}_{\mathrm{o}}$ : Males are more sensitive to public school enrolment during 2012/2013 academic session than females.

(ii). $\quad \mathrm{H}_{\mathrm{o}}$ : Males are more sensitive to public school enrolment during 2013/2014 academic session than females.

(iii). $\quad \mathrm{H}_{\mathrm{o}}$ : There is no significant difference between the male enrolments during the two academic sessions.

(iv). $\quad \mathrm{H}_{0}$ : There is no significant difference between the female enrolments during the two academic sessions.

\subsection{Population and Sample:}

Using systematic sampling in our school selection procedure, here $\mathrm{N}=288, \mathrm{n}=48$ and $k=\frac{N}{n}=6$. The forty-eight (48) schools selected using 
systematic sampling are: A.U.D Grammar school, Ikare, Akunnu Grammar school, Akunnu, Agbaode/Orimolade Grammar school, Ikare, Ajowa Commununity Grammar school, Ajowa, Comprehensive high school, Erusu, Ajiroke Technical high school, Arigidi, Isua Community Grammar school, Isua, African Church Grammar school, Oka, Ayegunle high School, Ayegunle Oke, Community Comprehensive high school, Akungba, Ejioba high school, Oba-ile, Igoba Community high school, Igoba, Omoluorogbo Grammar school, Akure, St. Dominic high school, Akure, St. Thomas Anglican Grammar school, Akure, Baptist high school, Akure, Okhuba-Ama high school, Ajapa, Community Comprehensive high school, Sabomi, Ebun-Ogunyimika Comprehensive high school, Atosin-Idanre, Anglican Grammar School, Igbare-Oke, C.A.C Comprehensive college, ljare, Iroko Comprehensive high school, Owode Owena, Community Grammar school, Araromi sea-side, Ereke Community Grammar school, Ereke, Mahin Community high school, Ode-Manin, Oloroke Grammar school, OkeIgbo, Community high school Oloruntele, Oko-Igbo, Awaye Comprehensive high school, Oloruntedo, Oluwasola Community Grammar school, Ile-Oluji, Oyenusi memorial Grammar school, Irele, Isero Grammar school, Odigbo, Comprehensive high school, Akinfolarin, Community high school, Rubber estimate, Stella-Maris college, Okitipupa, Manuwa memorial Grammar school, lju-Odo, Baptist Grammar school, Ode-Kiye, Community high school, Erekiti/Owoye, Community high School, Orisubare, Oladapo high school, Oladapo, Jubilee Community Grammar school, Ondo, St. Louis Senior school, Ondo, Community Grammar school, Oloruntedo, Ogo-Olorun C\&S Comprehensive high school, Ondo, Ifedapo Community Grammar school, Egure-Oba, Idohun high school, Idogun, Idoani Grammar school, Idoani, Methodist high school, Owo, Ipenmen Community Grammar school,
Owo. The detailed enrolments for the selected forty eight schools are shown in tables 1 and 2 in the appendix.

The same sets of schools are selected for the two academic sessions for easy comparison for the analysis with the total number of male enrolments in each school used as auxiliary variable and that of female used as variable of interest for hypotheses 1 and 2. For hypothesis 3 , total number of males enrolment in $2012 / 2013$ are used as auxiliary variable while their male counterpart during 2013/2014 are used as variable of interest, hypothesis 4 made used of their female enrolments counterpart. Hence, hypotheses 3 and 4 made used of male and female enrolments respectively.

For hypothesis $1 . \mathrm{H}_{\mathrm{o}}$ : Males are more sensitive to public school enrolment during 2012/2013 academic session than females.

Here, the sum total of males(x) and females(y) for each of the selected school during

2012/2013 academic session are used for the analysis where,

$$
\begin{array}{lr}
\rho_{m f(2012 / 2013)}=0.868, & t_{m f(2012 / 2013)}=11.858, \\
p-\text { value }_{m f(2012 / 2013)}<0.000 & \text { and } \\
t_{m f(2012 / 2013), 5 \%, 47 d f}=2.0117 &
\end{array}
$$

Here, since $\quad t_{m f(2012 / 2013)}(11.858) \quad>$ $t_{m f(2012 / 2013), 5 \%, 47 d f}(2.0117)$, we then conclude that females are more sensitive to public school enrolment during 2012/2013 academic session than their males counterparts.

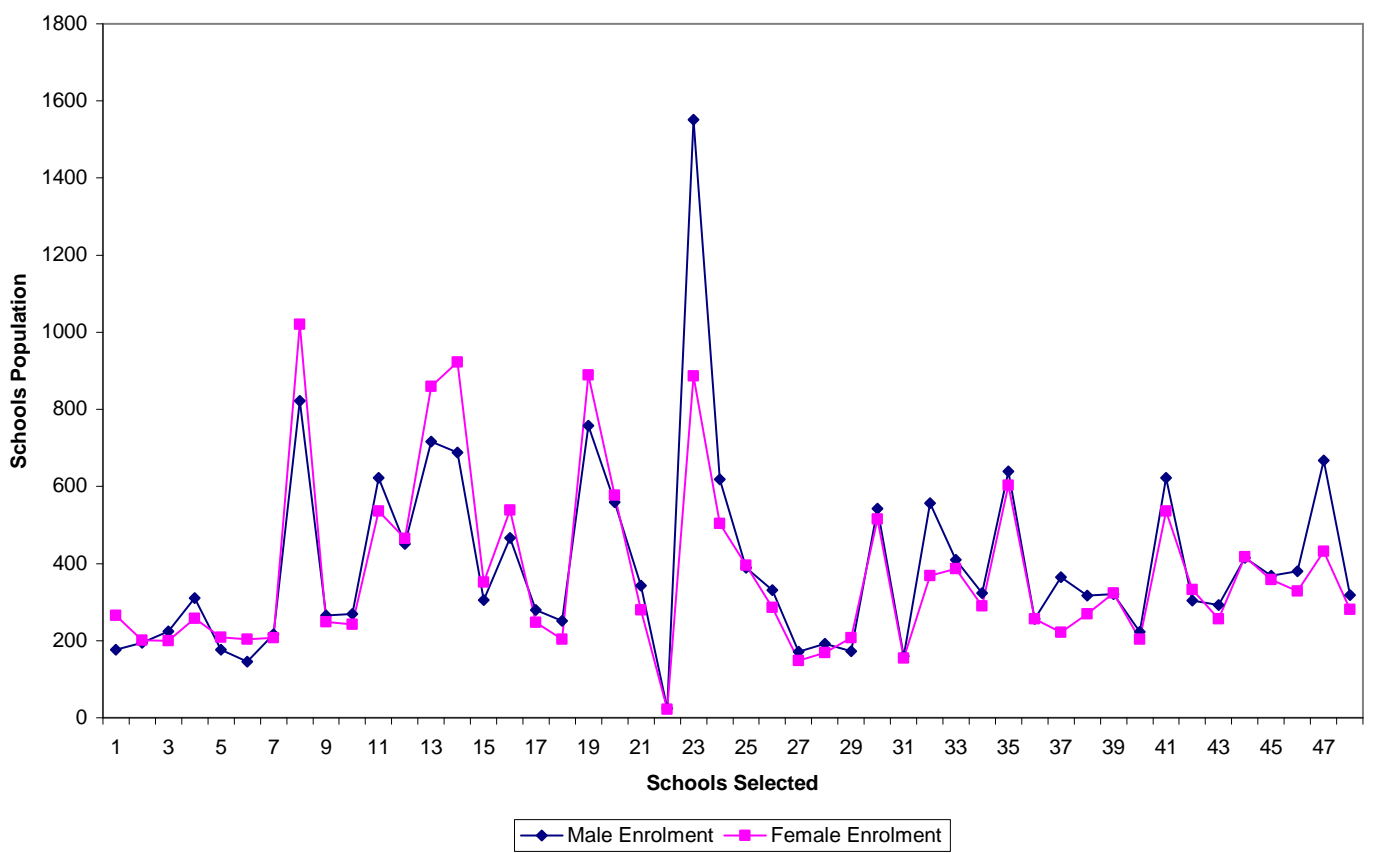

Figure 1: Male Female School Enrolment During 2012/2013 Academic Session 
Here, the trend of male female enrolment during 2012/2013 academic session are both downward and upward.

For hypothesis 2. $\mathbf{H}_{0}$ : Males are more sensitive to public school enrolment during 2013/2014 academic session than females.

Here, the sum total of males $(x)$ and females(y) for each of the selected school during 2013/2014 academic session are used for the analysis where,

$$
\begin{aligned}
& \rho_{m f(2013 / 2014)}=0.952, \quad t_{m f(2013 / 2014)}=21.017, \\
& \operatorname{sig} g_{m f(2013 / 2014)}<0.000 \\
& t_{m f(2013 / 2014), 5 \%, 47 d f}=2.0117 \\
& \text { Here, since } \quad t_{m f(2013 / 2014)}=21.017 \\
& t_{m f(2013 / 2014), 5 \%, 47 d f}=2.0117, \text { we then conclude that } \\
& \text { females are more sensitive to public school enrolment } \\
& \text { during 2013/2014 academic session than their males } \\
& \text { counterparts. }
\end{aligned}
$$

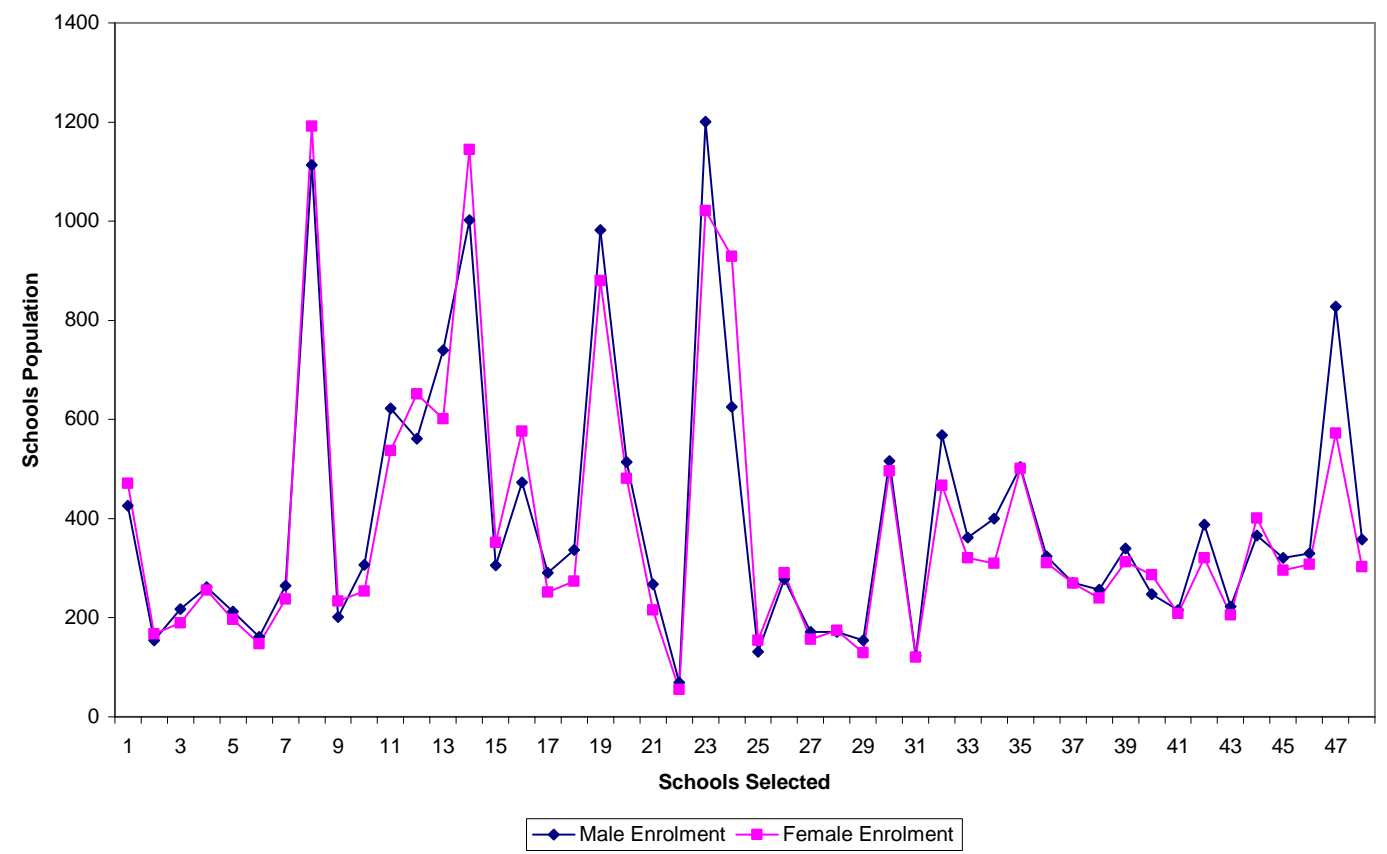

Figure 2: Male Female School Enrolment During 2013/2014 Academic Session

Here, the trend of male female enrolment during 2013/2014 academic session are both downward and upward.

For hypothesis $3 . \mathrm{H}_{0}$ : There is no significant difference between the male enrolments during the two academic sessions.

Here, the sum total of males(x) and males(y) for each of the selected public school during both 2012/2013 and 2013/2014 academic sessions are used for the analysis where,

$\rho_{m m(2012 / 2013,2013 / 2014)}=0.874, \quad t_{m m(2012 / 2013,2013 / 2014)}=12.197, \quad \operatorname{sig}_{m m(2012 / 2013,2013 / 2014)}<0.000 \quad$ and $t_{m m(2012 / 2013,2013 / 2014), 5 \%, 47 d f}=2.0117$

Here, since $t_{m m(2012 / 2013,2013 / 2014)}=12.197>t_{m m(2012 / 2013,2013 / 2014), 5 \%, 47 d f}=2.0117$, we then conclude that there is significant difference between the male enrolments during the two academic sessions. 


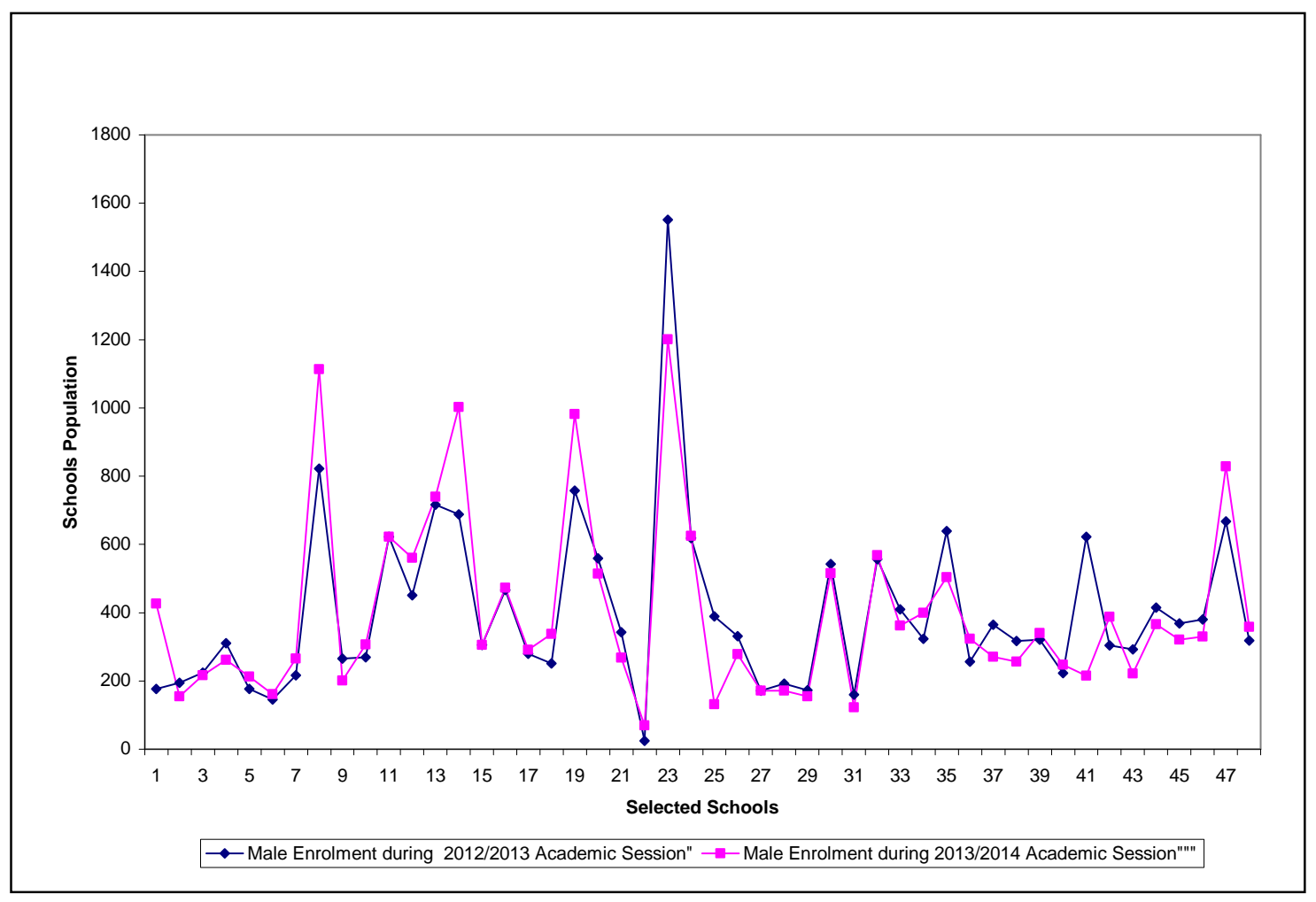

Figure 3: Male School Enrolment During 2012/2013 and 2013/2014 Academic Sessions

Except for few selected public schools, the trend of male enrolments shows little improvement during 2013/2014 over that of 2012/2013 academic session.

For hypothesis $4 . \mathbf{H}_{0}$ : There is no significant difference between the female enrolment during the two academic Sessions.

Here, the sum total of females(x) and females(y) for each of the selected school during

2012/2013 and 2013/2014 academic sessions are used for the analysis where, $\rho_{f f(2012 / 2013,2013 / 2014)}=0.892$,

$t_{\text {ff }(2012 / 2013,2013 / 2014)}=13.367$

$\operatorname{sig}_{f f(2012 / 2013,2013 / 2014)}<0.000$

and

$t_{f f(2012 / 2013,2013 / 2014), 5 \%, 47 d f}=2.0117$

Here, since $\quad t_{f f(2012 / 2013,2013 / 2014)}=13.367>$ $t_{f f(2012 / 2013,2013 / 2014), 5 \%, 47 d f}=2.0117$, we then conclude that there is significant difference between the female enrolments during the two academic sessions. 


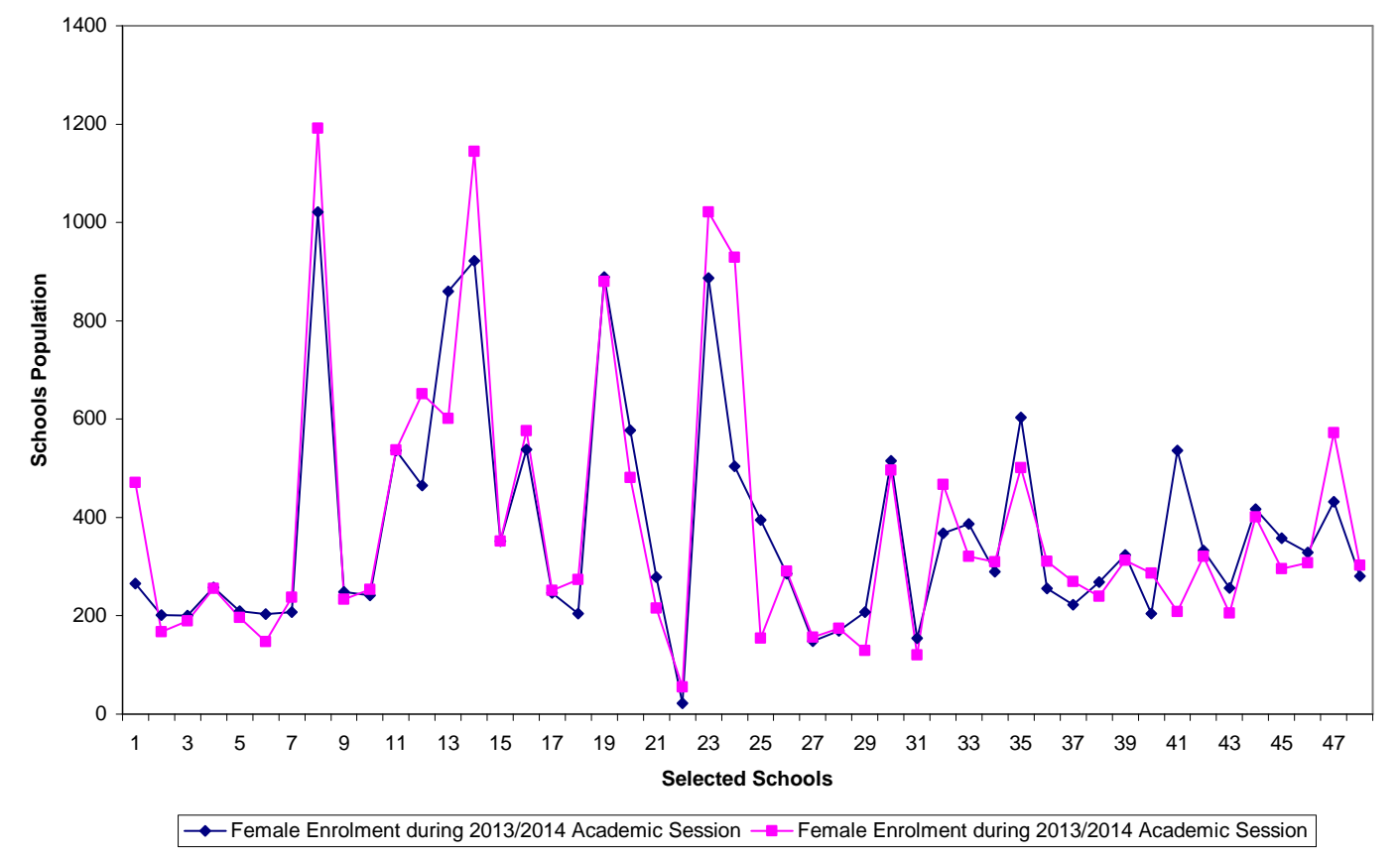

Figure 4: Female School Enrolment During 2012/2013 and 2013/2014 Academic Sessions

The trend of female enrolments in the selected public schools shows improvement during 2013/2014 over that of 2012/2013 academic session.

\section{CONCLUSION}

Based on the analysis carried out on the total number of males and females that enrolled in each of the selected forty eight public schools in Ondo State, Nigeria, we inferred that:

(i). females are more sensitive to public school enrolments during 2012/2013 and 2013/2014 academic sessions than their males counterparts.

(ii). there is significant difference between the female enrolments during the two academic sessions.

(iii). there is significant difference between the male enrolments during the two academic sessions and

(iv). the trend of female enrolments in the selected public schools shows improvement during 2013/2014 over that of 2012/2013 academic session.

\section{REFERENCES}

Adeniyi, A. A., 2014. Application of simple random sampling and systematic sampling to student's enrolment in public secondary schools in Ondo State, Nigeria (Department of Statistics, Federal University of Technology, Akure. Nigeria)
Adeyemi, T. O., 2008. Predicting students' performance in senior secondary certificate examinations from performance in junior secondary certificate examinations in Ondo State, Nigeria. Humanity and Social Science Journal, 3, (1): $26-36$.

Afolabi, F. O., 2000. Basic Concepts in School Administration and Supervision. Ondo: Patrick Ade Press Nig. Ltd.

Akpan, E. U. U., 2007. Educational Reforms and the Improvement of Educational Standards in Nigeria. Alead paper at a national conference of the Nigeria Primary and Teacher Association, held at University of Jos, Nigeria, July $30^{\text {th }}-$ $2^{\text {nd }}$ August.

Ige, A. M., 2013. Provision of secondary education in Nigeria: Challenges and way forward. Journal of African Sciences and Development. 5, (1): 1 -9.

Moja, T., 2000. Nigerian Education Sector Analysis: An Analytical Synthesis of performance and Main Issues. Paper prepared for World Bank Monograph Series, 1, (7): Abuja, Nigeria NUC

Ondo State Nigeria Ministry of Education., 2010. "Policy on student teacher ratio in schools" Akure: Ministry of Education Planning Research and Statistics Department. 2-5.

Ondo State Nigeria Ministry of Education., 2012. "Summary of school enrolment in Ondo State, Nigeria" 
Akure: Ministry of Education Planning Research and Statistics Department. 1-6.

Ondo State Teaching Service Commission., 2012. "School enrolment and teacher data" Akure: Ondo State Teaching Service Commission Planning Research and Statistics Department.26.

Oni, J.O., 1995. Educational resources: An introduction: Abeokuta Gbemi Sodipo press Itd.

Oruonye, E. D., 2014. The Challenges of Quality Secondary Education in Taraba State. Nigeria. Journal of Educational and Social Research: MCSER Publishing, Rome Italy. 4, (3): 499 505.

Rena, Ravinder., 1995. "The performance of Overseas Development Agency (ODA) Assisted Project on Andhra Pradesh Primary Education With Special Reference To Warangal District," Dissertation submitted for the award of M.Phil. Dgree in Economics, Department of Economics, Osmania University, Hyderabad, India

Rena, Ravinder., 2007. Factors affecting the enrolment and the retention of students at primary education in Andhra Pradesh a village level study. Essays in Education, 22, Fall 2007.

Tilak, J. B. G., 1987. Economics of Inequality in Education, Sage Publications, New Delhi.

Taiwo, C. O., 1983. The Nigerian education system; aims, plans and implementation. In Adesina, S, Akinyemi, K and Ajayi, K. (Eds). Nigerian education : friends and issues. Ile Ife, University of Ife Press Ltd. $45-52$.

Usman, H. N., 2008. Business Education in National Economic Reform Agenda. Journal of Education Research and Development. Faculty of Education, ABU, Zaria. 280 - 290.

Watson, J. R and Prieto, T., 2000. "Secondary Science in England and Spain" Education in Chemistry 31, (2): 41-45. 
Table 1: Enrolment of Public Secondary Schools for 2012/2013 Session in Selected Schools

\begin{tabular}{|c|c|c|c|c|c|c|c|c|c|c|c|c|c|c|c|}
\hline \multirow[t]{2}{*}{$\mathbf{S} / \mathbf{N}$} & \multirow[t]{2}{*}{ SCHOOLS } & \multirow[b]{2}{*}{$\begin{array}{l}\text { FOUN } \\
\text { DED }\end{array}$} & \multicolumn{2}{|c|}{ JSS I } & \multicolumn{2}{|c|}{ JSS11 } & \multicolumn{2}{|c|}{ JSS III } & \multicolumn{2}{|c|}{ SSS I } & \multicolumn{2}{|c|}{ SSS II } & \multicolumn{2}{|c|}{ SSS III } & \multirow{2}{*}{$\begin{array}{l}\text { GRAND } \\
\text { TOTAL }\end{array}$} \\
\hline & & & $\mathbf{M}$ & $\mathbf{F}$ & M & $\mathbf{F}$ & M & $\mathbf{F}$ & $M$ & $\mathbf{F}$ & $\mathbf{M}$ & $\mathbf{F}$ & $\mathbf{M}$ & $\mathbf{F}$ & \\
\hline 1 & $\begin{array}{l}\text { A. U. D. GRAMM. SCHL. } \\
\text { IKARE }\end{array}$ & 1962 & 21 & 26 & 37 & 40 & 55 & 64 & 39 & 59 & 30 & 47 & 35 & 30 & 483 \\
\hline 2 & $\begin{array}{l}\text { AKUNNU GRAMM. SCHL. } \\
\text { AKUNNU }\end{array}$ & 1978 & 34 & 31 & 28 & 29 & 32 & 35 & 30 & 31 & 35 & 36 & 36 & 39 & 396 \\
\hline 3 & $\begin{array}{l}\text { AGBAODE/ORIMOLADE } \\
\text { GRAMM. IKARE }\end{array}$ & 1980 & 39 & 41 & 56 & 43 & 30 & 29 & 29 & 34 & 34 & 23 & 36 & 30 & 424 \\
\hline 4 & $\begin{array}{l}\text { AJOWA COMM. GRAMM. } \\
\text { SCHOOL AJOWA }\end{array}$ & 1975 & 58 & 50 & 59 & 49 & 70 & 42 & 53 & 49 & 38 & 41 & 32 & 27 & 568 \\
\hline 5 & $\begin{array}{l}\text { COMP. HIGH SCHOOL } \\
\text { ERUSU }\end{array}$ & 1979 & 31 & 37 & 28 & 39 & 36 & 42 & 27 & 29 & 32 & 39 & 22 & 23 & 385 \\
\hline 6 & $\begin{array}{l}\text { AJIROKE TECHNICAL } \\
\text { HIGH SCHOOL ARIGIDI }\end{array}$ & 1980 & 24 & 22 & 28 & 31 & 31 & 44 & 22 & 35 & 26 & 44 & 14 & 27 & 348 \\
\hline 7 & $\begin{array}{l}\text { ISUA COMM. GRAMMAR } \\
\text { SCHOOL. ISUA }\end{array}$ & 1976 & 39 & 37 & 43 & 39 & 38 & 43 & 38 & 30 & 27 & 23 & 31 & 35 & 423 \\
\hline 8 & $\begin{array}{l}\text { AFRICAN } \\
\text { GRAMM. OKA }\end{array}$ & 1957 & 202 & 220 & 139 & 228 & 126 & 121 & 162 & 209 & 110 & 144 & 83 & 99 & 1843 \\
\hline 9 & $\begin{array}{l}\text { AYEGUNLE HIGH SCOOL } \\
\text { AYEGUNLE OKA }\end{array}$ & 1978 & 45 & 35 & 52 & 50 & 29 & 31 & 75 & 55 & 40 & 47 & 25 & 31 & 515 \\
\hline 10 & $\begin{array}{l}\text { COMM. COMP. H/S } \\
\text { AKUNGBA }\end{array}$ & 1980 & 51 & 37 & 46 & 47 & 36 & 34 & 49 & 41 & 53 & 46 & 34 & 37 & 511 \\
\hline 11 & $\begin{array}{l}\text { EJIOBA HIGH SCHOOL } \\
\text { OBA-ILE }\end{array}$ & 1976 & 97 & 76 & 154 & 129 & 102 & 87 & 108 & 93 & 94 & 88 & 67 & 63 & 1158 \\
\hline 12 & $\begin{array}{ll}\text { IGOBA COMM. HIGH } \\
\text { SCHOOL, IGOBA }\end{array}$ & 2007 & 127 & 123 & 121 & 103 & 68 & 72 & 51 & 69 & 62 & 67 & 22 & 31 & 916 \\
\hline 13 & $\begin{array}{l}\text { OMOLUOROGBO GRAM. } \\
\text { SCHOOL AKURE }\end{array}$ & 1976 & 123 & 162 & 174 & 181 & 127 & 155 & 133 & 182 & 107 & 118 & 52 & 62 & 1,576 \\
\hline 14 & $\begin{array}{l}\text { ST. DOMINIC HIGH } \\
\text { SCHOOL, AKURE }\end{array}$ & 1980 & 168 & 191 & 158 & 183 & 85 & 122 & 140 & 200 & 67 & 127 & 70 & 99 & 1,610 \\
\hline 15 & $\begin{array}{l}\text { ST. THOMAS } \text { ANG. } \\
\text { GRAMM. } \\
\text { AKURE }\end{array}$ & 1980 & 67 & 71 & 40 & 60 & 33 & 50 & 85 & 75 & 35 & 42 & 46 & 54 & 658 \\
\hline 16 & $\begin{array}{l}\text { BAPTIST HIGH SCHOOL } \\
\text { AKURE }\end{array}$ & 2001 & 127 & 148 & 95 & 118 & 75 & 88 & 75 & 82 & 64 & 57 & 30 & 45 & 1,004 \\
\hline 17 & $\begin{array}{l}\text { APOI NATIONAL HIGH } \\
\text { SCHOOL IGBOTU }\end{array}$ & 1979 & 48 & 51 & 51 & 39 & 54 & 55 & 47 & 35 & 39 & 34 & 41 & 33 & 527 \\
\hline 18 & $\begin{array}{l}\text { COMM. COMP. HIGH } \\
\text { SCHOOL IGBEKEBO }\end{array}$ & & 49 & 31 & 35 & 33 & 45 & 35 & 43 & 37 & 39 & 31 & 40 & 37 & 455 \\
\hline 19 & $\begin{array}{l}\text { ST. JOSEPH CATH. } \\
\text { GRAM. SCHL. IDANRE }\end{array}$ & 1980 & 203 & 207 & 193 & 186 & 144 & 145 & 138 & 120 & 7 & 165 & 72 & 66 & 1646 \\
\hline 20 & $\begin{array}{l}\text { ANGLICAN GRAMM. } \\
\text { SCHL. IGBARAOKE }\end{array}$ & 1958 & 115 & 123 & 102 & 115 & 106 & 95 & 102 & 103 & 82 & 84 & 52 & 57 & 1136 \\
\hline 21 & $\begin{array}{ll}\text { COMMUNITY } & \text { HIGH } \\
\text { SCHOOL ISARUN } & \end{array}$ & 1980 & 70 & 60 & 67 & 53 & 49 & 43 & 43 & 30 & 41 & 26 & 73 & 67 & 622 \\
\hline 22 & $\begin{array}{l}\text { UNITED } \\
\text { COMPREHENSIVE HIGH } \\
\text { SCHOOL IKOTA }\end{array}$ & 2010 & 3 & 4 & 4 & 10 & 10 & & 7 & 8 & & & & & 46 \\
\hline 23 & $\begin{array}{l}\text { ILAJE HIGH SCHOOL } \\
\text { IGBOKODA }\end{array}$ & 1979 & 299 & 163 & 308 & 152 & 276 & 170 & 266 & 182 & 287 & 143 & 115 & 77 & 2438 \\
\hline 24 & $\begin{array}{l}\text { COMM. GRAMM SCHOOL } \\
\text { ARAROMI SEA-SIDE }\end{array}$ & 1980 & 66 & 52 & 104 & 84 & 81 & 61 & 80 & 67 & 135 & 103 & 153 & 137 & 1123 \\
\hline 25 & $\begin{array}{l}\text { MAHIN COMM. H. S. ODE- } \\
\text { MANIN }\end{array}$ & 1981 & 56 & 54 & 50 & 55 & 52 & 50 & 60 & 65 & 80 & 82 & 91 & 89 & 784 \\
\hline 26 & $\begin{array}{l}\text { HOLY SAVIOURS H. S. } \\
\text { ILE-OLUJI }\end{array}$ & 1975 & 55 & 49 & 52 & 41 & 49 & 60 & 66 & 62 & 56 & 37 & 53 & 37 & 617 \\
\hline 27 & $\begin{array}{lr}\text { COMM. } & \text { H/S } \\
\text { OLORUNTELE, } & \text { OKE- } \\
\text { IGBO } & \\
\end{array}$ & 1980 & 33 & 25 & 33 & 28 & 27 & 26 & 27 & 29 & 18 & 19 & 34 & 21 & 320 \\
\hline 28 & $\begin{array}{l}\text { COMMUNITY GRAMM. } \\
\text { SCHL. AKINYE ILE-OLUJI }\end{array}$ & & 35 & 26 & 22 & 25 & 21 & 27 & 22 & 21 & 26 & 14 & 66 & 56 & 361 \\
\hline 29 & $\begin{array}{ll}\text { COMMUNITY } & \text { HIGH } \\
\text { SCHOOL ULOEN } & \end{array}$ & 2002 & 9 & 19 & 18 & 23 & 13 & 11 & 12 & 17 & 61 & 74 & 60 & 63 & 380 \\
\hline 30 & $\begin{array}{l}\text { ARERIN GRAMM. } \\
\text { SCHOOL IRELE }\end{array}$ & 1980 & 90 & 82 & 92 & 89 & 125 & 124 & 92 & 66 & 70 & 80 & 73 & 74 & 1057 \\
\hline 31 & $\begin{array}{l}\text { OMI COMM. GRAMM } \\
\text { SCHOOL, ODE-OMI }\end{array}$ & 2006 & 25 & 26 & 30 & 22 & 26 & 23 & 26 & 28 & 23 & 30 & 30 & 25 & 314 \\
\hline 32 & $\begin{array}{l}\text { KAJOLA COMM. GRAMM. } \\
\text { SCHOOL, KAJOLA }\end{array}$ & 1980 & 90 & 43 & 85 & 50 & 98 & 76 & 90 & 67 & 80 & 52 & 113 & 80 & 924 \\
\hline 33 & $\begin{array}{l}\text { COMM. HIGH SCHOOL } \\
\text { ASEWELE KOREDE }\end{array}$ & 1981 & 50 & 43 & 70 & 71 & 81 & 69 & 63 & 70 & 78 & 62 & 68 & 72 & 797 \\
\hline 34 & $\begin{array}{l}\text { COMM. HIGH SCHOOL, } \\
\text { ONIPARAGA }\end{array}$ & 2006 & 40 & 45 & 60 & 38 & 61 & 48 & 43 & 39 & 35 & 40 & 85 & 80 & 614 \\
\hline
\end{tabular}




\begin{tabular}{|c|c|c|c|c|c|c|c|c|c|c|c|c|c|c|c|}
\hline 35 & $\begin{array}{l}\text { IDEPE HIGH SCHL. } \\
\text { OKITIPUPA }\end{array}$ & 1976 & 89 & 70 & 100 & 140 & 115 & 117 & 98 & 85 & 135 & 100 & 102 & 91 & 1242 \\
\hline 36 & $\begin{array}{l}\text { LUBOKUN COMP. HIGH } \\
\text { SCHL. IGBOTAKO }\end{array}$ & 1979 & 39 & 43 & 37 & 33 & 33 & 35 & 41 & 40 & 43 & 44 & 64 & 61 & 513 \\
\hline 37 & $\begin{array}{l}\text { COMM. HIGH SCHOOL } \\
\text { MOBOLORUNDURO }\end{array}$ & 1980 & 36 & 14 & 48 & 32 & 39 & 32 & 75 & 51 & 75 & 36 & 91 & 57 & 586 \\
\hline 38 & $\begin{array}{l}\text { EKIMOGUN C. } \\
\text { BOLORUNDURO }\end{array}$ & 1976 & 43 & 39 & 47 & 49 & 63 & 61 & 56 & 52 & 57 & 37 & 51 & 31 & 586 \\
\hline 39 & $\begin{array}{l}\text { EPE COMMUNITY HIGH } \\
\text { SCHOOL EPE }\end{array}$ & 1980 & 49 & 41 & 53 & 61 & 53 & 47 & 50 & 58 & 40 & 50 & 76 & 67 & 645 \\
\hline 40 & $\begin{array}{l}\text { INDEPENDENCE } \\
\text { ONDO }\end{array}$ & 1962 & 42 & 41 & 38 & 43 & 34 & 22 & 49 & 44 & 42 & 42 & 18 & 12 & 427 \\
\hline 41 & $\begin{array}{lll}\text { IGBADO } & \text { C.G } & \text { SCHL. } \\
\text { IGBADO } & & \\
\end{array}$ & 1979 & 97 & 76 & 154 & 129 & 102 & 87 & 108 & 93 & 94 & 88 & 67 & 63 & 1158 \\
\hline 42 & $\begin{array}{l}\text { C.A.C. OKE-ISEGUN H/S } \\
\text { ONDO }\end{array}$ & 1980 & 47 & 65 & 61 & 76 & 88 & 106 & 32 & 21 & 46 & 36 & 30 & 29 & 637 \\
\hline 43 & $\begin{array}{l}\text { OLUWABASIRI } \\
\text { G/S ONDO }\end{array}$ & 1980 & 12 & 23 & 28 & 26 & 30 & 25 & 46 & 40 & 96 & 73 & 81 & 70 & 550 \\
\hline 44 & $\begin{array}{l}\text { COMMUNITY GRAMMAR } \\
\text { SCHOOL OLORUNTEDO }\end{array}$ & & 83 & 80 & 56 & 59 & 61 & 52 & 65 & 67 & 64 & 78 & 86 & 81 & 832 \\
\hline 45 & OKELUSE ANG. G. S. & 1975 & 61 & 63 & 68 & 65 & 67 & 70 & 66 & 57 & 43 & 47 & 64 & 56 & 727 \\
\hline 46 & $\begin{array}{l}\text { WORD OF FAITH C. } \\
\text { ARIMOGIJA }\end{array}$ & 1980 & 71 & 68 & 65 & 55 & 56 & 46 & 52 & 42 & 61 & 54 & 75 & 64 & 709 \\
\hline 47 & $\begin{array}{l}\text { METHODIST } \\
\text { SCHOOL OWO }\end{array}$ & 1965 & 120 & 86 & 126 & 74 & 113 & 72 & 130 & 90 & 85 & 65 & 94 & 45 & 1100 \\
\hline 48 & $\begin{array}{l}\text { COMM. GRAMM. SCHL. } \\
\text { EMURE ILE }\end{array}$ & 1980 & 79 & 58 & 67 & 31 & 73 & 66 & 33 & 47 & 44 & 43 & 22 & 36 & 599 \\
\hline
\end{tabular}

Table 2: Enrolment of Public Secondary Schools for 2013/2014 Session

\begin{tabular}{|c|c|c|c|c|c|c|c|c|c|c|c|c|c|c|c|}
\hline & SELECTED SCHOOLS & YEAR & JSS & & JSS & & JSS & & SS & & SS & & SS & & GRAND \\
\hline & & $\begin{array}{l}\text { FOUN } \\
\text { DED }\end{array}$ & M & $\mathrm{F}$ & M & $\mathrm{F}$ & M & $\mathrm{F}$ & M & $\mathrm{F}$ & M & $\mathrm{F}$ & M & $F$ & TOTAL \\
\hline 1 & $\begin{array}{l}\text { A. U. D. GRAMM. SCHL. } \\
\text { IKARE }\end{array}$ & 1962 & 73 & 77 & 70 & 99 & 73 & 95 & 75 & 65 & 77 & 73 & 58 & 62 & 897 \\
\hline 2 & $\begin{array}{l}\text { AKUNNU GRAMM. SCHL. } \\
\text { AKUNNU }\end{array}$ & 1978 & 20 & 23 & 34 & 37 & 14 & 21 & 31 & 33 & 29 & 34 & 26 & 19 & 321 \\
\hline 3 & $\begin{array}{l}\text { AGBAODE/ORIMOLADE } \\
\text { GRAMM. IKARE }\end{array}$ & 1980 & 32 & 27 & 36 & 34 & 51 & 37 & 21 & 27 & 38 & 42 & 39 & 22 & 406 \\
\hline 4 & $\begin{array}{l}\text { AJOWA COMM. GRAMM. } \\
\text { SCHOOL AJOWA }\end{array}$ & 1975 & 43 & 34 & 46 & 55 & 53 & 38 & 48 & 52 & 28 & 34 & 44 & 43 & 518 \\
\hline 5 & $\begin{array}{l}\text { COMP. HIGH SCHOOL } \\
\text { ERUSU }\end{array}$ & 1979 & 25 & 28 & 34 & 38 & 36 & 34 & 33 & 39 & 46 & 34 & 38 & 23 & 408 \\
\hline 6 & $\begin{array}{l}\text { AJIROKE TECHNICAL } \\
\text { HIGH SCHOOL ARIGIDI }\end{array}$ & 1980 & 21 & 29 & 30 & 24 & 26 & 24 & 33 & 29 & 27 & 21 & 24 & 20 & 308 \\
\hline 7 & $\begin{array}{l}\text { ISUA COMM. GRAMMAR } \\
\text { SCHOOL. ISUA }\end{array}$ & 1976 & 33 & 35 & 57 & 49 & 53 & 35 & 53 & 40 & 41 & 50 & 28 & 29 & 503 \\
\hline 8 & $\begin{array}{ll}\text { AFRICAN } & \text { CHURCH } \\
\text { GRAMM. OKA } & \end{array}$ & 1957 & 251 & 249 & 214 & 232 & 219 & 211 & 197 & 215 & 135 & 142 & 97 & 143 & 2,305 \\
\hline 9 & $\begin{array}{l}\text { AYEGUNLE HIGH SCOOL } \\
\text { AYEGUNLE OKA }\end{array}$ & 1978 & 23 & 37 & 29 & 35 & 40 & 44 & 30 & 31 & 40 & 45 & 39 & 42 & 435 \\
\hline 10 & $\begin{array}{l}\text { COMM. } \\
\text { AKUNGBA }\end{array}$ COMP. H/S & 1980 & 49 & 36 & 51 & 44 & 54 & 42 & 48 & 46 & 52 & 39 & 53 & 47 & 561 \\
\hline 11 & $\begin{array}{l}\text { EJIOBA HIGH SCHOOL } \\
\text { OBA-ILE }\end{array}$ & 1976 & 97 & 76 & 154 & 129 & 102 & 87 & 108 & 93 & 94 & 89 & 67 & 63 & 1,159 \\
\hline 12 & $\begin{array}{l}\text { IGOBA COMM. HIGH } \\
\text { SCHOOL, IGOBA }\end{array}$ & 2007 & 158 & 164 & 120 & 140 & 99 & 140 & 80 & 100 & 52 & 62 & 52 & 45 & 1,212 \\
\hline 13 & $\begin{array}{l}\text { OMOLUOROGBO GRAM. } \\
\text { SCHOOL AKURE }\end{array}$ & 1976 & 117 & 93 & 136 & 114 & 90 & 87 & 201 & 141 & 97 & 102 & 99 & 64 & 1,341 \\
\hline 14 & $\begin{array}{l}\text { ST. DOMINIC } \\
\text { SCHOOL, AKURE }\end{array}$ & 1980 & 200 & 237 & 194 & 224 & 128 & 185 & 173 & 206 & 175 & 129 & 132 & 163 & 2,146 \\
\hline
\end{tabular}




\begin{tabular}{|c|c|c|c|c|c|c|c|c|c|c|c|c|c|c|c|}
\hline 15 & ST. THOMAS ANG. & 1980 & 67 & 71 & 40 & 60 & 33 & 50 & 85 & 75 & 35 & 42 & 46 & 54 & 658 \\
\hline 16 & $\begin{array}{l}\text { BAPTIST HIGH SCHOOL } \\
\text { AKURE }\end{array}$ & 2001 & 120 & 169 & 80 & 112 & 60 & 82 & 103 & 113 & 52 & 52 & 58 & 48 & 1,049 \\
\hline 17 & $\begin{array}{l}\text { APOI NATIONAL HIGH } \\
\text { SCHOOL IGBOTU }\end{array}$ & 1979 & 53 & 58 & 54 & 42 & 43 & 28 & 61 & 62 & 42 & 33 & 38 & 29 & 543 \\
\hline 18 & $\begin{array}{l}\text { COMM. COMP. } \\
\text { SCHOOL IGBEKEBO }\end{array}$ & 1980 & 66 & 52 & 70 & 52 & 53 & 36 & 70 & 53 & 49 & 55 & 29 & 26 & 611 \\
\hline 19 & $\begin{array}{l}\text { ST. JOSEPH CATH. GRAM. } \\
\text { SCHL. IDANRE }\end{array}$ & 1980 & 215 & 156 & 201 & 217 & 164 & 159 & 150 & 116 & 135 & 123 & 117 & 109 & 1,862 \\
\hline 20 & $\begin{array}{l}\text { ANGLICAN } \\
\text { SCHL. IGBARAOKE }\end{array}$ & 1958 & 85 & 80 & 103 & 95 & 100 & 96 & 89 & 76 & 87 & 81 & 50 & 53 & 995 \\
\hline 21 & $\begin{array}{ll}\text { COMMUNITY } & \text { HIGH }\end{array}$ & 1980 & 52 & 45 & 55 & 53 & 46 & 38 & 43 & 34 & 37 & 26 & 35 & 19 & 483 \\
\hline 22 & $\begin{array}{l}\text { UNITED COMPREHENSIVE } \\
\text { HIGH SCHOOL IKOTA }\end{array}$ & 2010 & 16 & 12 & 18 & 17 & 13 & 7 & 7 & 9 & 10 & 4 & 5 & 6 & 124 \\
\hline 23 & $\begin{array}{l}\text { ILAJE HIGH SCHOOL } \\
\text { IGBOKODA }\end{array}$ & 1979 & 242 & 221 & 175 & 170 & 226 & 190 & 250 & 197 & 217 & 163 & 91 & 80 & 2,222 \\
\hline 24 & $\begin{array}{l}\text { COMM. GRAMM SCHOOL } \\
\text { ARAROMI SEA-SIDE }\end{array}$ & 1980 & 58 & 67 & 115 & 90 & 76 & 62 & 95 & 78 & 149 & 138 & 132 & 94 & 1,154 \\
\hline 25 & $\begin{array}{l}\text { MAHIN COMM. H. S. ODE- } \\
\text { MANIN }\end{array}$ & 1981 & 15 & 11 & 16 & 16 & 19 & 19 & 17 & 18 & 16 & 19 & 48 & 71 & 285 \\
\hline 26 & $\begin{array}{l}\text { HOLY SAVIOURS H. S. } \\
\text { ILE-OLUJI }\end{array}$ & 1975 & 50 & 47 & 44 & 55 & 41 & 46 & 47 & 52 & 47 & 45 & 49 & 46 & 569 \\
\hline 27 & $\begin{array}{l}\text { COMM. H/S OLORUNTELE, } \\
\text { OKE-IGBO }\end{array}$ & 1980 & 30 & 31 & 30 & 30 & 30 & 28 & 32 & 28 & 25 & 21 & 24 & 18 & 327 \\
\hline 28 & $\begin{array}{lc}\text { COMMUNITY } & \text { GRAMM. } \\
\text { SCHL. AKINYE ILE-OLUJI }\end{array}$ & 1980 & 19 & 19 & 23 & 27 & 23 & 25 & 32 & 29 & 40 & 36 & 34 & 38 & 345 \\
\hline 29 & $\begin{array}{ll}\text { COMMUNITY } & \text { HIGH } \\
\text { SCHOOL ULOEN } & \end{array}$ & 2002 & 23 & 11 & 29 & 20 & 14 & 18 & 32 & 25 & 37 & 32 & 19 & 23 & 283 \\
\hline 30 & $\begin{array}{l}\text { ARERIN GRAMM. SCHOOL } \\
\text { IRELE }\end{array}$ & 1980 & 99 & 77 & 86 & 84 & 80 & 81 & 80 & 98 & 83 & 88 & 88 & 68 & 1,012 \\
\hline 31 & $\begin{array}{l}\text { OMI COMM. GRAMM } \\
\text { SCHOOL, ODE-OMI }\end{array}$ & 2006 & 15 & 16 & 20 & 25 & 25 & 23 & 30 & 20 & 15 & 20 & 18 & 16 & 243 \\
\hline 32 & $\begin{array}{l}\text { KAJOLA COMM. GRAMM. } \\
\text { SCHOOL, KAJOLA }\end{array}$ & 1980 & 63 & 67 & 93 & 77 & 90 & 48 & 94 & 77 & 105 & 94 & 123 & 104 & 1,035 \\
\hline 33 & $\begin{array}{l}\text { COMM. HIGH SCHOOL } \\
\text { ASEWELE KOREDE }\end{array}$ & 1981 & 38 & 36 & 67 & 63 & 65 & 72 & 65 & 62 & 78 & 62 & 49 & 26 & 683 \\
\hline 34 & $\begin{array}{l}\text { COMM. HIGH SCHOOL, } \\
\text { ONIPARAGA }\end{array}$ & 2006 & 60 & 42 & 70 & 42 & 55 & 65 & 70 & 56 & 80 & 50 & 65 & 55 & 710 \\
\hline 35 & $\begin{array}{l}\text { IDEPE HIGH } \\
\text { OKITIPUPA }\end{array}$ & 1976 & 67 & 77 & 80 & 94 & 73 & 95 & 102 & 82 & 99 & 92 & 83 & 61 & 1005 \\
\hline 36 & $\begin{array}{l}\text { LUBOKUN COMP. HIGH } \\
\text { SCHL. IGBOTAKO }\end{array}$ & 1979 & 55 & 60 & 56 & 60 & 56 & 58 & 42 & 49 & 50 & 44 & 65 & 40 & 635 \\
\hline 37 & $\begin{array}{l}\text { COMM. HIGH SCHOOL } \\
\text { MOBOLORUNDURO }\end{array}$ & 1980 & 39 & 46 & 47 & 41 & 50 & 52 & 48 & 43 & 54 & 51 & 33 & 37 & 541 \\
\hline 38 & $\begin{array}{l}\text { EKIMOGUN C. } \\
\text { BOLORUNDURO }\end{array}$ & 1976 & 58 & 45 & 42 & 43 & 43 & 65 & 39 & 33 & 38 & 42 & 37 & 12 & 497 \\
\hline
\end{tabular}




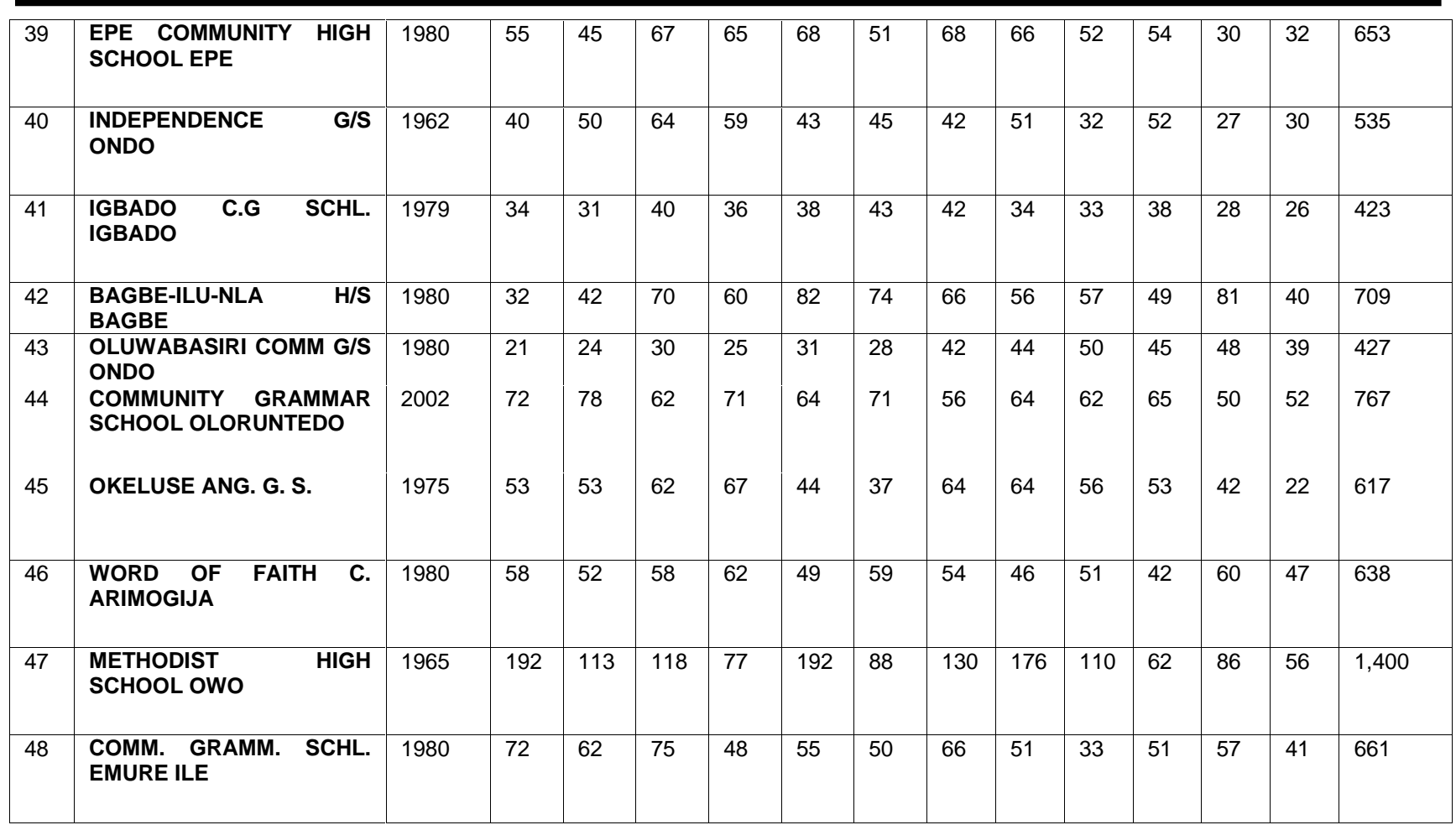

Source:- (1).Ondo State Nigeria Ministry of Education (2013): "Summary of school enrolment in Ondo State, Nigeria" Akure: Ministry of Education Planning Research and Statistics Department.

(2). Adeniyi, 2014 